\title{
Peristylus intrudens - An addition to the orchid flora of India from Andaman and Nicobar Islands
}

\author{
Joju P. Alappatt \\ Department of Environment and Forests, Forest Training Institute, Wimberlygunj, \\ Andaman and Nicobar Islands - 744206, India. \\ E-mail: jojualappatt@yahoo.com
}

\begin{abstract}
Peristylus intrudens (Ames) Ormerod (Orchidaceae) is reported here as an addition to the orchid flora of India from Andaman and Nicobar Islands. A brief description with illustration and photographs is provided for easy identification.
\end{abstract}

Keywords: Orchidaceae, Peristylus, India, New Report

\section{Introduction}

Peristylus Blume is a genus of 103 species belonging to the subfamily Orchidoideae of family Orchidaceae, distributed from Mascarenes, tropical and subtropical Asia to Mongolia and Pacific region (Govaerts et al., 2017). The genus is represented by 29 species and 2 varieties in India (Misra, 2007), of which 5 species are reported from Andaman and Nicobar Islands (Pandey \& Diwakar, 2008; Karthigeyan et al., 2010, 2014; Alappatt, 2015; Murugan et al., 2016). The general morphology of this genus is very similar to that of Habenaria Willd. and Pecteilis Raf. but can easily be differentiated from them on the basis of stigmatic lobes being connate or adpressed to the lip base and by the presence of erect ovary close to the rachis.

During floristic explorations in Andaman group of islands, a few specimens belonging to the genus Peristylus were collected from South Andaman Island. On critical study, they were identified as Peristylus intrudens (Ames) Ormerod. A thorough scrutiny of literature (Sinha, 1999; Misra, 2007; Rao, 2007; Pandey \& Diwakar, 2008; Kumar et al., 2010; Ormerod, 2011; Karthigeyan et al., 2014; Alappatt, 2015; Prabhukumar et al., 2016) revealed that this species was hitherto unrecorded from Andaman and Nicobar Islands and mainland India as well. Hence, it is reported here as an addition to the orchid flora of India. A brief description along with illustration and photographs (Figs. 1,2) is provided to facilitate easy recognition of this species in the field.

Peristylus intrudens (Ames) Ormerod, Taiwania 56(1): 46. 2011; Raskoti et al., J. Jap. Bot. 87: 137.
2012. Habenaria intrudens Ames, Schedul. Orchid. 6: 1.1923.

Figs. 1, 2

Terrestrial herb, to $40 \mathrm{~cm}$ high; tubers subglobose to ellipsoid, c. $1.5 \times 1 \mathrm{~cm}$ with several slender roots at the neck. Stem leafy at basal part, c. $20 \mathrm{~cm}$ long, bearing 2 or 3 tubular sheathing leaves below; basal sheathing leaves to $1 \mathrm{~cm}$ long, covering the stem base to $1.5 \mathrm{~cm}$ high. Leaves 3-5, spreading near stem base, lanceolate-oblong, 7-15 × 2-3 $\mathrm{cm}$, sheathing at base, acute, apiculate at apex. Inflorescence a raceme, terminal, c. $15 \mathrm{~cm}$ long, erect, 10-20-flowered; peduncle c. $21 \mathrm{~cm}$ long, glabrous with 3-5 sheathing bracts; sterile bracts suberect, linear-lanceolate, $1.5-3 \mathrm{~cm}$ long, acuminate; floral bracts lanceolate, 5-15 × 2.5-5 $\mathrm{mm}$, acuminate at apex, light green. Flowers c. 2 $\mathrm{mm}$ across, creamy white, not opening widely; pedicels with ovary equal to or slightly longer than floral bracts, cylindric-fusiform, c. $1.2 \mathrm{~cm}$ long, erect and held close to the rachis, twisted, glabrous; dorsal sepal and petals form a hood over the column. Dorsal sepal elliptic-ovate, concave, c. $3 \times 1.5 \mathrm{~mm}$, subacute to obtuse at apex; lateral sepals concave, narrowly oblong, c. $3 \times 1.5$ $\mathrm{mm}$, acute at apex; petals erect forming a hood with dorsal sepal, oblong, shallowly concave, c. $4 \times 2 \mathrm{~mm}$, acute at apex, thinly textured. Lip c. $3 \mathrm{~mm}$ long, deflexed, deeply 3-lobed towards apex, base united with the lateral sepals; lateral lobes spreading, narrowly triangular, c. $1 \times 0.5$ $\mathrm{mm}$, shorter than midlobe; midlobe triangularlanceolate, c. $1.5 \times 0.5 \mathrm{~mm}$, acute at apex; spur broadly ovoid, c. $1.5 \times 1 \mathrm{~mm}$, bent forward with acute apex; disk with a prominent subglobose 


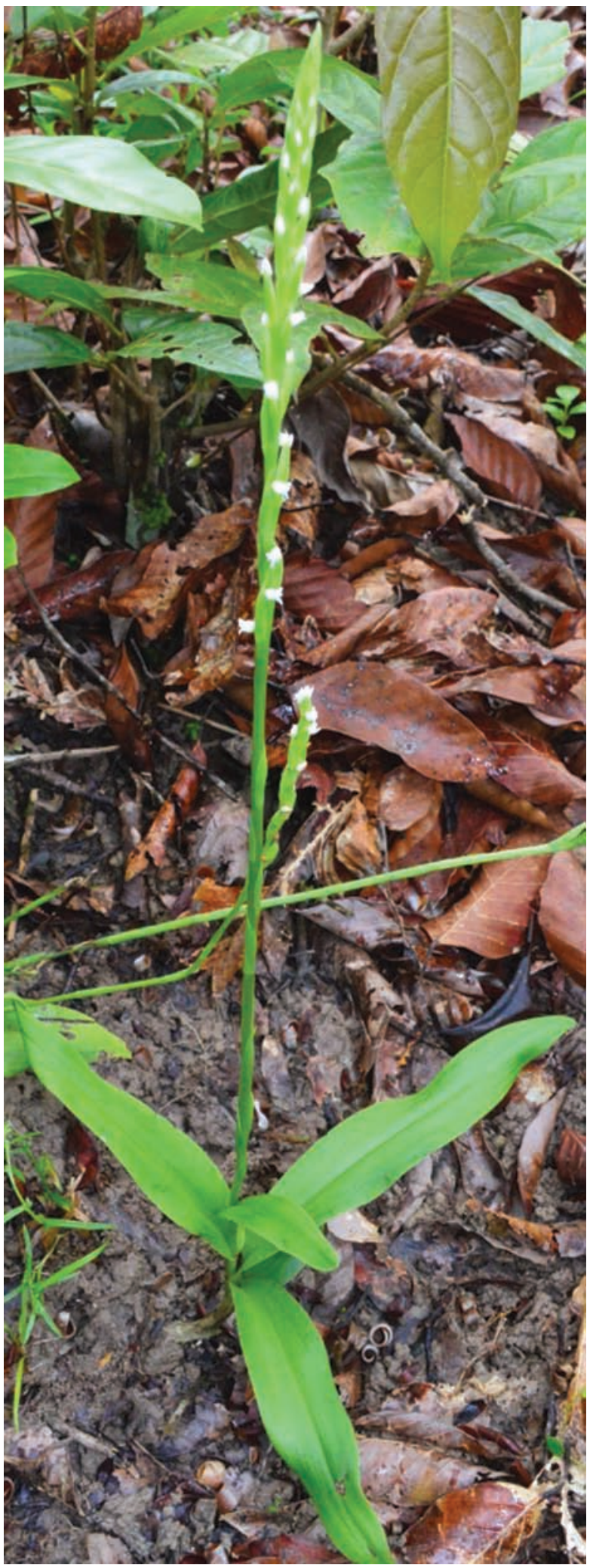

Fig. 1. Peristylus intrudens (Ames) Ormerod.

callus near base in front of the spur cavity. Column c. $1 \mathrm{~mm}$ long with large auricles on both sides; stigma small, placed near to the auricles. Fruits ellipsoid, c. $1 \times 0.5 \mathrm{~cm}$, sessile.
Flowering E Fruiting: October-January.

Habitat: A rare ground orchid found in moist and shady places of semievergreen forests growing along with Selaginella ciliaris (Retz.) Spring, Scleria lithosperma (L.) Sw., Lindsaea ensifolia Sw. and Eriocaulon sp. at an elevation of c. $25 \mathrm{~m}$.

Distribution: Nepal, China (Hong Kong), Taiwan, Philippines and now in India; also found in Myanmar and Thailand (Hubert Kurzweil, pers. comm.).

Specimens examined: INDIA, Andaman and Nicobar Islands, South Andaman Island, Kalatang, 7.11.2015, Joju P. Alappatt 1206 (PBL); Kalatang, 22.10.2016, Joju P. Alappatt 1369 (Herbarium Forest Training Institute, Wimberlygunj). CHINA, Hong Kong, Tai Po, S.Y. Hu 10944 (K000827047, image!)

Note: This species is closely related to P. lacertifer (Lindl.) J.J. Sm. but differs from it in having white flowers, shorter lip side lobes and more elliptic petals.

\section{Acknowledgements}

The author is grateful to Dr. Alok Saxena, IFS, PCCF, Department of Environment and Forests, Andaman and Nicobar Islands, for providing facilities and support, Dr. Hubert Kurzweil, Researcher, Singapore Botanic Garden and Dr. Paul Ormerod, Australia, for critical comments on the identity of the specimen.

\section{Literature Cited}

Alappatt, J.P. 2015. Peristylus gracilis (Orchidaceae): An addition to the Flora of Andaman \& Nicobar Islands, India. Rheedea 25(1): 36-38.

Govaerts, R., Campacci, M.A., Baptista, D.H., Cribb, P.J., George, A., Kreutz, K. \& J.J. Wood 2017. World Checklist of Orchidaceae. Royal Botanic Gardens, Kew. [http:/ /apps.kew.org/ wcsp/; retrieved on 3.01.2017].

Hsu, T.C. \& S.W. Chung 2009. Supplements to the orchid Flora of Taiwan (I). Taiwania 54(1): 82-87.

Karthigeyan, K., Sumathi, R. \& J. Jayanthi 2010. Peristylus balakrishnanii (Orchidaceae), a new species from the Andaman archipelago, India. Kew Bull. 65: 491-493.

Karthigeyan, K., Jayanthi, J., Sumathi, R. \& J.S. Jalal 2014. A review of the orchid diversity of Andaman \& Nicobar Islands. Richardiana 15: 9-85. 


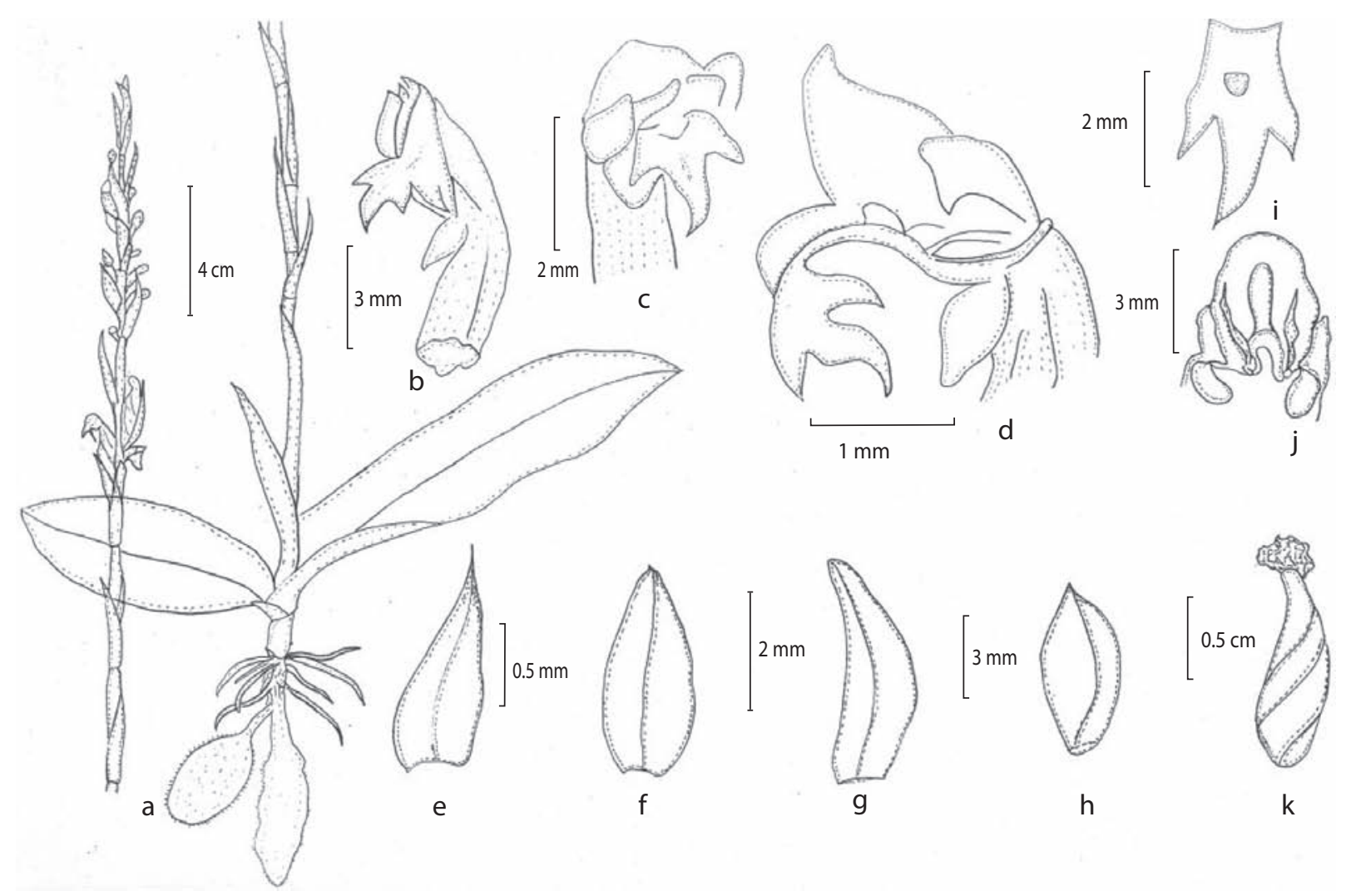

Fig. 2. Peristylus intrudens (Ames) Ormerod: a. Habit; b,c. Flower (side and front views); d. Flower (close-up); e. Floral bract; $\mathrm{f}, \mathrm{g}$. Sepals (dorsal and lateral views); h. Petal; i. Lip; j. Column; k. Fruit (Joju P. Alappatt 1206, PBL).

Kumar, P., Rawat, G.S. \& J.S. Jalal 2010. Peristylus sahanii, a new species of Orchidaceae from India. Kew Bull. 65: 101-104.

Misra, S. 2007. Orchids of India: A glimpse. Bishen Singh Mahendra Pal Singh, Dehra Dun.

Murugan, C., Prabhu, S., Sathiyaseelan, R. \& R.P. Pandey 2016. A checklist of plants of Andaman and Nicobar Islands. (Edited by P. Singh \& W. Arisdason). ENVIS Centre on Floral Diversity, Botanical Survey of India, Howrah. Published on the Internet http:/www.bsienvis.nic.in/ database/Checklist-of-Nicobar-islands24427. aspx (accessed on 28th October 2016)

Ormerod, P. 2011. Orchidaceous additions to the Flora of China. Taiwania 56(1): 42-49.

Pandey, R.P. \& P.G. Diwakar 2008. An integrated checklist Flora of Andaman and Nicobar Islands, India. J. Econ. Taxon. Bot. 32(2): 403-500.
Prabhukumar, K.M., Naveen Kumar, V.V., Bhavadas, N., Sunil, C.N., Pankaj Kumar \& Indira Balachandran 2016. Peristylus tentaculatus (Orchidaceae): A new record for India from the Western Ghats of Kerala. Rheedea 26(1): 77-79.

Rao, A.N. 2007. Orchid flora of North-East India An up-to-date analysis. Bull. Arunachal Forest Res. 23(1\&2): 6-38.

Sinha, B.K. 1999. Flora of Great Nicobar Island. (Edited by P.K. Hajra \& P.S.N. Rao). Botanical Survey of India, Calcutta.

Received: 3.4.2017

Revised and Accepted: 2.6.2017 